\title{
Educational level and future expectations of the children who pick waste papers
}

\author{
Sultan Bilge Keskinkılıç Kara ${ }^{1}$
}

\begin{abstract}
Due to poverty, many children begin to work on the streets and in the informal sector although they need to continue their education. Children who work on the streets usually pick waste papers and their job continue whole day. Therefore they are forced to drop out of school. Waste pickers who are at the age of compulsory education may appear to be a problem for both the country and the education system. The aim of this study is to determine the educational levels and the future expectations of the children who work on the streets by picking waste papers instead of continuing their education. According to the findings, a great majority of the children who pick waste papers are males. The results reveal that the most of them work because of poverty, their age range from 13 to 15 and they drop out of school after 5 years of education. Although the most of them want to go to school and have a job as a policeman or army officer, they see their future ambiguous.
\end{abstract}

Keywords: Working Children; Children Who Pick Waste Papers; Future Expectation

\section{Introduction}

Child labour is one of the major problems in our country and around the world. According to the data of International Program on the Elimination of Child Labour (IPEC) (2010), there are 215 million working children in the world. In Turkey, 958 thousand children between the ages of 6-18 are involved in child labour according to the statistics of Turkish Statistical Institute (TUIK). The statistics do not report the number of children working on the streets. Child labour creates major problems in terms of socialization, growing in a healthy way and preparation for the future. Moreover when the shortcomings in the economic conditions are added, it becomes a more

\footnotetext{
1 Assistant Professor Doctor, Okan University, Faculty of Education, Department of Educational Sciences, bilge.kara@,okan.edu.tr
} 
Keskinkiliç Kara, S. B. (2014). Educational level and future expectations of the children who pick waste papers. International Journal of Human Sciences, 11(1), 78-88. doi: 10.14687/ijhs.v11i1.2704

important issue and major problems arise such as children who work on the streets (Friedrich Ebert Association, 1992).

Poverty is the main cause of child work (Keskinkılıç-Kara and Çalık, 2012; Alacahan, 2010; Tor, 2010; ILO/TİSK/TÜRK-İS, 2007; İkizoğlu et al., 2007; Kambhampatı and Rajan, 2006; Basu, 2005; Suryahadi et al., 2005; Bakırc1, 2004). Working children quit school at an early age, cannot receive adequate educational services so they cannot participate fully in social life. According to a research conducted by Goulart and Bedi (2007) child's one hour work in any job causes \%4 decrease in his academic grade. In a research carried out by Heady (2003), it's determined that the academic grades of the working children are lower than the non-working children's grades. Each one hour work of child increases the likelihood of quitting his school at the rate of 1.6 (Rosati and Rossi, 2001). According to a study performed by Gunnarsson et al (2006), in 10 countries, child's work outside home for an hour decreases his maths grade at the rate of $\% 10$ and decreases his Science grade at the rate of $\% 15$. These studies have shown that child labour decreases the success at school. As the children do not have any education and master any profession, this may bring a lot of disadvantages into their life in future and even this may lead to vicious circle of poverty.

Children who pick waste papers are forced to leave school; when problems with their families increase, they may run away from home and they spend large amount of their time on streets. The studies conducted by some researchers suggested that the majority of children working on the streets also left the school at the same time (Sisman, 2006; Fisek, 2004). Another study conducted by Alp et al. (2000) has revealed that, although $19.4 \%$ of the children working on streets were older than seven and that they were illiterate. The research conducted by Karataş et al. (1994) about the children working on the streets of Antalya has revealed that, $42.2 \%$ of these children are attending primary school, $25 \%$ of the children graduated from primary school, $14.1 \%$ of the children dropped out of primary school, and $6.2 \%$ of the children never went to school. Among the reasons for dropping out of school, "unwillingness" and "failure to succeed in school" have a ratio of 57.9\% (Fişek, 2004). These conditions can be linked with the educational system's inability to understand and guide every single child.

Children should stay in houses and continue their education. Some studies in this area have revealed that there are lots of candidates that may become street children by losing their relationship with their families and connection with their schools (Karabulut, 1996). Protecting children from all kinds of negative conditions and preparing them for the future are important in terms of both human rights and social development. In consideration of the importance of this 
Keskinkiliç Kara, S. B. (2014). Educational level and future expectations of the children who pick waste papers. International Journal of Human Sciences, 11(1), 78-88. doi: 10.14687/ijhs.v11i1.2704

aspect, it seems to be necessary to get to know the children picking waste paper and to define their future expectations, in order to solve their problems, since an individual's behaviour is not only determined by his/her past experience; but also determined by his/her future expectations (Adler, 1994). However, the present conditions affect the content and the level of these expectations.

\section{Expectations for Future}

Expectation is the pre-assumption of an individual about the terms and conditions that will take shape in the future or the expectations from himself/herself. Future expectations have important roles for his/her purpose-driven life. In this context, the child's social environment and the importance of infrastructure constituted by the society for the future of an individual should be considered. It is the education that a child receives, his/her individual gains and the gains that his/her environment offers that shape the child's future expectations. Future expectations are the cognitive maps hosting the interests and concerns of individuals. From a theoretical point of view, future expectation has a strong impact and guidance on individuals while it helps them to make decisions in current conditions (Nurmi, 1991). School environments are important institutions in terms of the future expectations of individuals (Kuzmaz and Bilgin, 2010). In this context, all levels of educational organisations and managers have great responsibilities.

Individuals' future expectations provide important information for educators, sociologists and policy makers. They primarily contain information about the levels of satisfaction with their lives. Additionally, they provide data for the education and guidance services. It includes information about how and to what extent the existing developments are perceived. It may have an important role on preventing harmful addictions. Individuals, who are raised with higher expectations for the future, demonstrate increased learning capacity, become more productive, and gain satisfaction in an individual and social base with the help of increasing performance (Tuncer, 2011). According to the studies related to future expectations, the students who have future expectations demonstrate social harmony, independent decision-making traits and have positive values which in return improve the individual's psychological state (Şimşek, 2012; Catalano et al., 2004). It is considered that children, who can define and manage their future expectations, may stop leaving their school, and not suffer from drug addiction and social imbalances.

This study aims to determine the educational levels and future expectations of children who cannot go to school and contribute to the family budget by working, although at the age of compulsory education. 
Keskinkiliç Kara, S. B. (2014). Educational level and future expectations of the children who pick waste papers. International Journal of Human Sciences, 11(1), 78-88. doi: 10.14687/ijhs.v11i1.2704

\section{Method and Material}

A semi-structured interview technique is used in the study. This technique enables the researcher to investigate the research questions with wider perspective and deeper understanding. In this context, explanations are made from time to time when the participants were not able to respond to questions. In this process, special attention was given to help the participants to express their thoughts.

\section{Study Group}

The chain sampling method was used to determine the study group. The researcher conducted the study in Sekermurat Quarter, Konya where most of the children who pick waste papers reside along with their families, and particularly Sunday was chosen as it is a day off. Families with waste paper stacks in front of their houses were selected for interviews, since this clearly indicates that they are making their living by picking waste paper. The researcher explained the aims of the study and asked whether they knew any of the children that pick paper instead of going to school, although at the age of compulsory education and whether they knew anybody that they would recommend talking to. The answers to the questions directed researchers to the other children. The study group consisted of 28 children. 25 (89.29\%) children participating in the study were male and $3(10.71 \%)$ children were female.

Table 1: The ages of the study group

\begin{tabular}{ccc}
\hline Age & $\mathbf{f}$ & $\mathbf{\%}$ \\
\hline 9 years old & 1 & 3.57 \\
\hline 10 years old & 2 & 7.14 \\
\hline 11 years old & 2 & 7.14 \\
\hline 12 years old & 4 & 14.28 \\
\hline 13 years old & 6 & 21.42 \\
\hline 14 years old & 7 & 25.00 \\
\hline 15 years old & 6 & 21.42 \\
\hline TOTAL & 28 & 100 \\
\hline
\end{tabular}

It was seen that the most of the participants were between the ages of 13-15. Accordingly, 67.8\% of the children were of the age to attend secondary school and $32.2 \%$ of the children were of the age to attend elementary school. 
Keskinkiliç Kara, S. B. (2014). Educational level and future expectations of the children who pick waste papers. International Journal of Human Sciences, 11(1), 78-88. doi: 10.14687/ijhs.v11i1.2704

\section{Data Collection Tool}

Semi-structured interviews designed by the researcher were used in the study. A literature review was conducted for the purposes of creating a research interview form and the list that was intended to be used for interview purposes to investigate the subject had been prepared and included 7 questions. Then this form was presented for evaluation by education and measurement field specialists and according to their suggestions, the number of questions was decreased from 7 to 5 . A pilot study was conducted in order to determine the comprehensibleness of questions with four of children who pick waste papers were chosen at random and interviewed. One of the interview questions was amended due to its unclarity. The interview items representing five main issues, namely the duration of time spent in school, the reasons for not going to school, future plans, what they wanted to be when they grew up and how they saw their future.

\section{Data Collection and Analysis}

By using a data collection tool prepared by the researcher to collect data, 28 children picking waste paper and do not attend school in spite of being at the age of compulsory education were interviewed. The data was collected in July and August 2011 through face-to-face interviews conducted by the researcher. Children were interviewed in their homes or on the street by their houses with the permission of their parents. During the interviews, along with the interview form, voice recording was performed with the permission of the participants. Recorded interviews were transcribed by the researcher.

In the Findings and Comments section of this study, some of the participants' responses to the questions were used on an as-is basis. In order to easily understand and compare, the parts that participants especially emphasized in their answers were used to create a table.

\section{Results}

Table 2: Duration of time spent in school

\begin{tabular}{ccc}
\hline Duration & $\mathbf{f}$ & $\mathbf{\%}$ \\
\hline 3 years & 5 & 17.85 \\
\hline 4 years & 3 & 10.71 \\
\hline 5 years & 11 & 39.28 \\
\hline 6 years & 5 & 17.85 \\
\hline Never attended a school & 4 & 14.28 \\
\hline TOTAL & 28 & 100 \\
\hline
\end{tabular}


Keskinkiliç Kara, S. B. (2014). Educational level and future expectations of the children who pick waste papers. International Journal of Human Sciences, 11(1), 78-88. doi: 10.14687/ijhs.v11i1.2704

$39.28 \%$ of the children participating in the study left school after 5 years of education. $17.85 \%$ of the children attended school for 3 and 6 years and left the school after that. 10.71\% of the children went to school for 4 years, and $14.28 \%$ of the children never attended a school.

\section{Reasons for not going to school}

The researcher obtained interesting results regarding the reasons. The results are shown on Table 3 .

Table 3: The emphasised points as the reasons why the children did not go to school

\begin{tabular}{|c|c|c|c|}
\hline Emphasised points & Sample Answers & f & $\%$ \\
\hline Poverty & $\begin{array}{l}\text { Y.R. "I couldn't attend school because we were poor. I } \\
\text { have to earn money for my family." }\end{array}$ & 18 & 64.28 \\
\hline School Failure & $\begin{array}{l}\text { D.F. "Because of having low school success I didn't go } \\
\text { to school. Also for this reason, my parents didn't insist } \\
\text { me to go to school." }\end{array}$ & 5 & 17.85 \\
\hline Exclusion & $\begin{array}{l}\text { M.Y. "My school mates used to exclude me. They used } \\
\text { to call me 'Gipsy'. They were always despising me". }\end{array}$ & 3 & 10.71 \\
\hline $\begin{array}{l}\text { Physical and verbal } \\
\text { abuse }\end{array}$ & $\begin{array}{l}\text { R.G. "Students at the school used to beat me. When I } \\
\text { complain about this situation, my teachers and the } \\
\text { managers used to rebuke me and sometimes they beat } \\
\text { too." }\end{array}$ & 2 & 7.14 \\
\hline TOT & & 28 & 100 \\
\hline
\end{tabular}

The results indicated that, poverty was the major reason amongst the children who did not go to school. Amongst 28 children, 18 children (64.28\%) supported this idea by indicating that the main reason for not going to school was poverty. Another reason was the school failure (17.85\%). Three of the children $(10.71 \%)$ indicated that the reason for not going to school was the exclusion by fellow students. Two children (14.7\%) stated that they quit going to school due to the physical and verbal abuse that they receive from teachers and students.

\section{Children's Expectations for Their Future}

To determine the major expectations of children with regard to their future, the emphasised parts of the answers given to questions were stated, and some of the answers were used on an "as-is" basis in order to create a table and an analysis was performed on the findings. 
Keskinkiliç Kara, S. B. (2014). Educational level and future expectations of the children who pick waste papers. International Journal of Human Sciences, 11(1), 78-88. doi: 10.14687/ijhs.v11i1.2704

Table 4: Children's expectations for their future

\begin{tabular}{llcc}
\hline \multicolumn{1}{c}{ Emphasised points } & \multicolumn{1}{c}{ Sample Answers } & f & \% \\
\hline Go to school & E.N. "I want to go to school, so I can change my life.” & 11 & 39.28 \\
\hline A good job & $\begin{array}{l}\text { S.F. "I want to have a good job, a sanitary job. I wish I } \\
\text { were a computer programmer." }\end{array}$ & 6 & 21.42 \\
\hline Having a happy life & Ç.Ç. "I wish a good life. I want to be happy." & 4 & 14.28 \\
\hline Being wealthy & Ö.C. "I want to be rich, and look after my parents." & 3 & 10.71 \\
\hline A good family & Y.R. "I wish a good family, a good husband and lots of \\
& children." & 2 & 7.14 \\
\hline No expectation & F.De. "I wish nothing. Things will go like this" & 2 & 7.14 \\
\hline TOTAL & & 28 & 100 \\
\hline
\end{tabular}

When the table was examined, it was determined that the children (39.28\%) firstly wanted to go to school; secondly, $21.42 \%$ of the children wanted to have a good job. $14.28 \%$ of the children wanted to be happy in the future while $14.7 \%$ indicated their desire to have a good family. The results were interesting; $10.71 \%$ of the children wanted to become wealthy, instead of having a good job. $7.14 \%$ of the children stated that they had no expectations at all.

Table 5: Jobs that children would like to do in the future

\begin{tabular}{lll}
\hline \multicolumn{1}{c}{ Job } & $\mathbf{f}$ & $\mathbf{0}$ \\
\hline Policeman & 9 & 32.14 \\
\hline Military officer & 5 & 17.85 \\
\hline Teacher & 5 & 17.85 \\
\hline A job with social security & 4 & 14.28 \\
\hline Engineer & 2 & 7.14 \\
\hline Computer programmer & 2 & 7.14 \\
\hline Doctor & 1 & 3.57 \\
\hline TOTAL & 28 & 100 \\
\hline
\end{tabular}

According to the research, the children (32.14\%) picking waste paper firstly wanted to become a policeman; secondly, they wanted to become a military officer and a teacher with a ratio of $17.85 \%$. Except those who wanted to have a job with social security $(14.28 \%$ ), all of the children were willing to have jobs that require a college degree. 
Keskinkiliç Kara, S. B. (2014). Educational level and future expectations of the children who pick waste papers. International Journal of Human Sciences, 11(1), 78-88. doi: 10.14687/ijhs.v11i1.2704

Table 6: How the children see their future

\begin{tabular}{llcc}
\hline \multicolumn{1}{c}{ Emphasised points } & \multicolumn{1}{c}{ Sample Answers } & f & \% \\
\hline Don't know & M.O:“I don't know but I hope it will be better” & 11 & 39.29 \\
\hline Having a different job & $\begin{array}{l}\text { E. A: "My dad doesn't want me to do this job. He will } \\
\text { let me work with my uncle." }\end{array}$ & 5 & 17.86 \\
\hline Doing the same job & $\begin{array}{l}\text { F. Ö: "I think I will go on picking waste paper. I don't } \\
\text { want this job but I have nothing else.” }\end{array}$ & 5 & 17.86 \\
\hline Establish a family & M.Y: "I will get married and have children.” & 3 & 10.71 \\
& & & \\
\hline Going to school & $\begin{array}{l}\text { S. G: "I will enrol distance primary school and then } \\
\text { high school. I may pass the university exam.” }\end{array}$ & 3 & 10.71 \\
\hline Other & F.D: "I will grow up and join the army” & 1 & 3.57 \\
\hline TOTAL & & 28 & 100 \\
\hline
\end{tabular}

A large percentage of the children (39.29\%) responded with "I don't know" when they were asked "How do you see your future?". The percentage of children who think that they will work in a different job is equal to the percentage of children who think that they will continue to pick waste paper. All the answers regarding the wish to establish a family were given by girls. Girls provided no answers about their will to work or go to school, or they said "I do not know".

\section{Discussion}

A significant number of children participating in the study appear to be between the ages of 12-15. According to these data, it can be said that these children started to work on the streets at an early age. The majority of the children were boys. These findings reflect parallel results to previous studies about children working on the streets (Keskinkılıc-Kara and Çalık, 2012; Şişman, 2006). The reason for the majority of the children being males could be that families want to protect their daughters from sexual abuse which they could be exposed to on the streets (Kevin,1999; Muchini and Nyandiya-Bundy, 1991) as well as that the paper picking job requires more physical power than the other jobs done in the streets.

All the participants in the study were children that do not attend school although at the age range for compulsory education. Even some of the children who participated in the study never attended school previously. Most of the children, who previously attended an educational institution, left the school after five years of education. These findings were similar to those results of previous studies (Karatas et al., 1994; Alp et al., 2000). Although some kinds of jobs were suitable both for working and attending school at the same time (Admassie, 2003), owing to the reason that picking waste paper requires a shift of several hours, the children working at this job may need to leave school. 
Keskinkiliç Kara, S. B. (2014). Educational level and future expectations of the children who pick waste papers. International Journal of Human Sciences, 11(1), 78-88. doi: 10.14687/ijhs.v11i1.2704

The major cause of not attending the school is poverty. Families need their children to work because of poverty. Poverty was demonstrated as the reason for child labour in previous studies, and is in concordance with the findings of this study. In this context, it can be said that poverty increases the risk of dropping out of school (Sirin et al., 2004). The second reason for not attending school is failing in exams and being humiliated by fellow students. Results of a survey conducted by Baştaymaz (1990) in Bursa on working children that were at the age of 6-15, demonstrated that children lost connection with education and also due to failure to succeed in school they were not willing to go to school. Battin-Pearson et al. (2000) conducted a study investigating the reasons for leaving school, which suggests that academic failure has an important impact. The teachers and school staff that are perceived as being negligent, unfair and discouraging and exposure to abuse at school, as well as a negative atmosphere and disciplinary measures that are ignorant of problematic behaviours in school, have an impact in leaving the school (Suh \& Suh, 2006). Although there was a small number of students who claimed that the reason for leaving school was due to being abused and ostracised by fellow students and teachers, this finding is still remarkable. This situation can be explained by social learning theory. The students, who were exposed to physical and verbal abuse by the teacher, by observing these behaviours, learn to act abusively and start to reflect the same behaviours with their fellow students. Thus, the abusive behaviour of the teachers seems to have an indirect impact on abusive behaviours that can be observed between the students. Jenson (2006) stated that the main reason for ostracism was poverty and emphasised that ostracism is at the core of the poverty concept. Therefore, poverty causes ostracism of the children and ostracism turns out to become a socially vicious cycle, which in the end forces the child to leave the school.

Starting the 2012-2013 school year, compulsory education has been raised to 12 years in Turkey. With this new regulation, children are required to benefit at least from the basic education known as primary school. Supporting the children's involvement in the educational system is the most effective way to keep them away from working. It is known that investing in humans gives the most guaranteed results, though it is a long-term investment (Hazan and Berdugo, 2002: 826; Karaman and Ozcalik, 2007: 38).

Amongst the children's requests about the future, desire to go to school was in the first place, and when it is considered that these children do not go to school, it is an upsetting situation. Children are aware of the benefits of education for themselves; however, due to poverty and other reasons, they cannot benefit from it. The children having no expectations became pessimistic due to the difficult living conditions at the present. Also, despite being at the age of compulsory education and not going to school, all the children want to have a job that requires a university education. This 
Keskinkıliç Kara, S. B. (2014). Educational level and future expectations of the children who pick waste papers. International Journal of Human Sciences, 11(1), 78-88. doi: 10.14687/ijhs.v11i1.2704

situation can be interpreted as the children being unaware of their position or this may show that they are hopeful for the future. Unfortunately, without having any education they cannot have a job, so, this becomes a dream rather than a goal. Indeed, when they are asked "How do you see your future?", they were not as positive as the time they were specifying their desires.

Children who pick papers in order to help their families instead of living their childhood are one of the major problems of our country in terms of human rights, education, economy and health. To eliminate the undesirable situation that pushes children to work instead of attending school, the main step should include taking precautions against the reasons for this situation. Although the major responsibility should be carried by the government - from civil society organisations to schools - there are always essential steps that can be taken by every level of the system, because the solution to this problem requires versatile applications.

\section{References}

Adler, A. (1994). İnsan tabiatın tanıma. Ankara: Türkiye İş Bankası Kültür Yayınları.

Admassie, A. (2003). Child labour and schooling in the context of a subsistence rural economy: can they be compatible? International Journal of Educational Development 23, 167-185 Retrieved September 5, 2012, from www.elsevier.com/locate/ijedudev adresinden 19.12.2012

Alacahan, O. (2010). Çocuğunu sokakta çalıştıran ailelerin sosyo-ekonomik profilleri, tutum ve beklentileri. Sosyal Siyaset Konferanslar, 59(2), 133-147.

Alp, H., Özkan, B., Altınkaynak, S., Orbak,Z., Yiğit, H., \& Ertekin, V. (2000). Erzurum'da sokakta çalışan çocukların sosyo-demografik özellikleri. Türk Pediatri Arşivi, 35(2), 119-123

Bakırcı, K. (2004). Cocuk ve genç iş̧̧ilerin haklarmm korunması. İstanbul: Beta Yayınları.

Basu, K. (2005). Child labor and the law: notes on possible pathologies. Economics Letters, 87,169174

Baştaymaz, T. (1990). 6-15 yas grubu Bursa'da çalışan çocuklar üz̨erine bir araştırma. İstanbul: Friedrich Ebert Vakfi.

Battin-Pearson, S., Newcomb, M. D., Abbot, R. D., Hill, K. G., Katalano, R. F. and Hawkins, J. D. (2000). Predictors of early high school dropout. a test of five theories. Journal of Educational Psychology, 92 (3), 568-582.

Catalano, R. F., Berglund, M. L., Ryan, J. A. M., Lonczak, H. S., \& Hawkins, J. D. (2004). Positive youth development in the United States: Research findings on evaluations of positive youth development programs. The Annuals of the American Academy of Political and Social Science, 591, 98-124.

Fişek, A. G. (1994). Çocuk hakları yasası ve çalışan çocuklar. Mülkijyeliler Birliüi Dergisi, 19 (179180), 22-30

Goulart, P. \& Bedi, A. S. (2007). Child labour and educational success in Portugal. Economics of Education Review. Retrieved August 27, 2012, from www.elsevier.com/locate/econedurev

Gunnarsson, V., Orazem, P. and Sanchez, M. (2006-January). Child labor and school achievement in Latin America. World Bank Economic Review, 20,31-54

Heady, C. (2003). The effect of child labor on learning achievement. World Development, 31(2), 385-398.

Hazan, M., Berdugo, B. (2002). Child labour, fertility, and economic growth. Economic Journal, 112(482), 810-828 DOI: 10.1111/1468-0297.00066 
Keskinkiliç Kara, S. B. (2014). Educational level and future expectations of the children who pick waste papers. International Journal of Human Sciences, 11(1), 78-88. doi: 10.14687/ijhs.v11i1.2704

İkizoğlu, M., Önal Dölek, B., Gökçearslan Çifçi, E. (2007). Çalışan çocukların sorunları ve geleceğe ilişkin beklentileri. Toplum ve Sosyal Hirmet. 18(2), 21-36.

IPEC (International Programme for the Elimination of Child Labour) (2011) Children in hazardous work -What we know, what we need to do? Retrieved August 27, 2012, from http://www.ilo.org/ipecinfo/product/viewProduct.do?productId=17035

Jenson, J., M. and Fraser, M. (2006). Social Policy for Children and Families: A Risk And Resilience Perspective, Sage Publications, California.

Kambhampat, U., Rajan, R. (2006) Economic growth: a panacea for child labor? World Development ,34(3), 426-445.

Karabulut, Ö. (1996). Türkiye'de çalı̧san çocuklar. İstanbul: Çözüm Yayıncilık.

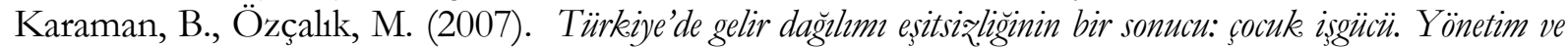
Ekonomi, Celal Bayar Üniversitesi I.I.I.B.F. Dergisi, 14(1), 25-41

Karataş, A., Ulutaş, Y., Erdemir, A. \& Küçüksümbül, N. (1994). Antalya sokaklarında çalışan çocuklar üzerine bir araştırma. IV. Ulusal Sosyal Hið̨met Konferansi, Bildiriler 3. Ankara.

Keskinkılıç-Kara, S. B. \& Çalık, T. (2012). Educational needs of the children working on the streets. GEFAD / GUJGEF 32(3): 673-695.

Kevin, J., L. (1999). Street children: a comparatıve perspectıve. Child Abuse \& Neglect, 23(8), 759_ 770.

Kızmaz, Z. \& Bilgin, R. (2010). Sokakta çalışan/yaşayan çocuklar ve suç: Diyarbakır örneği. Elektronik Sosyal Bilimler Dergisi, 9(32),271-311 Retrieved September 8 , 2012, from http://www.cteds.adalet.gov.tr/menusayfalari/bilgibankasi/makaleler/zahirkizmazmakaleleri/zahirkizm az_sokaktayasayancocuklar.pdf

Muchini, B., \& Nyandiya-Bundy, S. (1991). Struggling to survive: A study of street children in Zimbabwe. Harare, Zimbabwe: UNICEF.

Nurmi, J. E. (1991). How do adolescents see their future? A review of the development of futureorientation and planning. Developmental Review, 2, 1-59.

Rosati, F.C.\& Rossi, M (2001). Children's working hours, school enrolment and human capital accumulation: evidence from Pakistan and Nicaragua. Understanding Children's Work (Uow) Project Working Paper. Unicef. Retrieved August 25, 2012, from http://www.ucwroject.org/pdf/publications/standard_workinghours_humancapital.pdf

Suh, S. \& Suh, J. (2006). Educational engagement and degree attainment among high school dropouts. Educational Research and Quarterly, 29 (3), 11-20.

Şimşek, H. (2012) Güneydoğu anadolu bölgesindeki lise öğrencilerinin gelecek beklentileri ve gelecek beklentilerini etkileyen faktörler, Kuramsal Ë̈itimbilim Dergisi, 5(1), 90-109

Şirin, S.R., Matthew A. D., Lisa R. J., Gonsalves, L. \& Howell, A. 2004. Future aspirations of urban adolescents: a person-in-context model, International Journal of Qualitative Studies of Education, 17 (3), 437-59.

Şişman, Y. (2006). Sokakta çalışan çocukların yasam koşulları ve gelecek beklentileri. Anadolu Üniversitesi Sosyal Bilimler Dergisi, 2, 251-275

TİSK/ILO/Türk-İş (2007). Dünyada ve Türkiye'de çalışan çocnklar. Ankara: TŞOF Trafik Matbaacilik.

Tor, H. (2010). Türkiye'de çocuk işciliğinin boyutları. Zfwtt, 2 (2), 25-42

Tuncer, M. (2011). Ergen gelecek beklentileri ölçeğinin Türkçeye uyarlanmasi, Turkish Studies International Periodical For The Languages, Literature and History of Turkish or Turkic, 6 (3), 12651275 Retrieved September 5, 2012, from http://www.turkishstudies.net/Makaleler/1226543973_79_murat_tuncer.pdf

TÜİK (Türkiye İstatistik Kurumu) (2006). Çocuk işgücü araştırması. Retrieved September 5, 2012, from http:/www.tuik.gov.tr/prehaberbultenleri.do? İd=482 